Journal of Urban and Regional Analysis, vol. XI, 2, 2019, p. $173-183$

https://doi.org/10.37043/JURA.2019.11.2.4

\title{
ASPECTS OF SELF-ESTEEM IN THE TOURISM DEVELOPMENT IN KARO REGENCY, NORTH SUMATERA, INDONESIA
}

\author{
Nurlisa GINTING, N. Vinchy RAHMAN, Achmad D. NASUTION \\ University of Sumatera Utara, Medan, Indonesia
}

\begin{abstract}
Due to its positive effects on the economy, tourism is a significant aspect in the development of a country. Therefore, it is necessary to improve facilities at tourism destinations as well as to especially increase the local people's self-esteem in order to maintain such destinations. The study aims to examine self-esteem referring to the assessments given by tourists and residents in which such assessments can be used to improve the maintenance of tourist attractions in a region. As one of the regencies in North Sumatera Province, Karo owns great tourism potentials due to its various natural attractions as well as cultural richness. However, many of these attractions are not well maintained so self-esteem is considered as a solution. This study has measured four aspects namely evaluation, pride, attachment, and commitment which must become parts of Karo's identity. This study used the mix method which utilized a combination of 360 questionnaires and in-depth interviews. The findings show that the aspects of pride, attachment, and commitment became the positive features by the local residents although the assessment to the aspect is poorly evaluated. Moreover, the quality of infrastructures available at main tourism destinations was proved to increase also the residents' quality of life.
\end{abstract}

Key Words: self-esteem, tourism, place identity, Karo regency.

\section{Introduction}

Tourism has a strong contribution to the national and international advancement of a city and a nation. This sector is exceedingly prominent because it can improve the economy and the quality of life of the people (Ginting and Wahid 2015). Considering its profits and benefits, selfesteem in the tourism areas is the key aspect to determine people's positive or negative evaluation of the place (Wang and Xu 2015). This study aims to investigate the perceptions of citizens and tourists on the self-esteem aspect and its influences to the tourism development (henceforth TD) in Karo regency (henceforth KR) while the results can then be used for a tourism development program that leads to the improvement of the regional economy.

Karo is one of the regencies in North Sumatra (NS), which has various natural as well as cultural tourism attractions. It is also well-known for its agricultural products, such as fruits and vegetables, which local people and tourists can buy in the fruit markets (North Sumatera Culture and Tourism Office 2011). However, such wealthy resources have not been wellmaintained to its optimal value. One evidence of this is the lack of arrangement and maintenance of tourism objects to serve the tourists in the most desirable way. In addition, it is still difficult for tourists to find common facilities at tourist destinations (TTDs). Therefore, this study aims to examine a key principle which is called self-esteem in the TTDs and its important role in establishing identity of TTDs in KR. This research emphasizes the identification of selfesteem in some TTDs; the self-esteem is based on the aspects of evaluation, pride, attachment, and commitment. These findings will be used for assessments and references by the local governments to issue policies for the development of TTDs. It is believed that having well maintained TTDs based on the identity of the TTDs will benefit KR and its people, particularly those who occupy land around the research areas. 


\section{Literature review}

Place identity is a result of human responses to the changes of the physical environment in order to maintain a relationship with the place (Bonaiuto et al. 1996, Gustafson 2001) and its existence roots in many forms, both tangible and intangible, and it contributes to the identity of its society (Ginting and Rahman 2016a). This perception is essential to the TTD as a placebased phenomenon whose outcome involves place identity (Wang 2016, Ginting et al. 2017).

Self-esteem is a term referring to self-evaluation (Ginting and Rahman 2016b) in which people in an area measure themselves by giving a positive or negative appraisal to a place and how the place affects their feelings. The term relates to a person's sense of worth or of social value (Twigger-Ross and Uzzell 1996). For example, people feel proud of a place that has special characteristics (Ujang and Zakariya 2015). The appraisal does not only affect the identity of the surveyed person but also of the place (Proshansky et al. 1983) to make it more valuable. For example, a person or a group of people prefer a place having its physical characteristics that can increase their self-esteem compared to a place giving them bad effects to their esteem (Hauge 2007, Bajracharya 2015). Thus, visible symbols or characteristics as well as the historical value of a place will advance tourism because it can generate pride both for the tourists and the local people. Furthermore, as more tourists visit a place, they will be surprised with the pleasant neighborhood and therefore it can support their self-esteem (Twigger-Ross and Uzzell 1996). A person will feel close to a place through a process and what he/she feels may reflect his/her behavioral, cognitive, and emotional experiences towards the social and physical environments (Bernardo and Palma 2005). Commitment to a place is addressed to a discussion on the intensity of the desire to live in a city and on the attention to the development of a place in the future (Lalli 1992, Shabak et al. 2015). In short, self-esteem is divided into four variables, namely evaluation, pride, attachment and commitment (Table 1).

Variables of self-esteem principle

Table 1

\begin{tabular}{|l|l|l|l|}
\hline \multicolumn{4}{|c|}{ Self-Esteem Principle } \\
\hline \multicolumn{1}{|c|}{ Evaluation } & \multicolumn{1}{|c|}{ Pride } & \multicolumn{1}{c|}{ Attachment } & \multicolumn{1}{c|}{ Commitment } \\
\hline $\begin{array}{l}\text { - Respondent's } \\
\text { perceptions to } \\
\text { a positive } \\
\begin{array}{l}\text { assessment of } \\
\text { a place }\end{array}\end{array}$ & $\begin{array}{l}\text { - Perceptions of } \\
\text { respondents to the } \\
\text { history of a place or } \\
\text { past memories }\end{array}$ & $\begin{array}{l}\text { - Perceptions of } \\
\text { respondents to } \\
\text { feelings bound to a } \\
\text { place }\end{array}$ & $\begin{array}{l}\text { - Respondent's } \\
\text { perception on the } \\
\text { intensity of desire to } \\
\text { stay }\end{array}$ \\
& $\begin{array}{l}\text { - Perception of } \\
\text { respondents to } \\
\text { physical symbols / } \\
\text { characteristics }\end{array}$ & $\begin{array}{l}\text { - Respondents' } \\
\text { perceptions of the } \\
\text { sense of belonging to } \\
\text { a place }\end{array}$ & $\begin{array}{l}\text { - Respondents' } \\
\text { perceptions on the } \\
\text { development of a place } \\
\text { in the future }\end{array}$ \\
\hline
\end{tabular}

\section{Methodology}

\section{Research area}

The research was conducted in Karo regency which becomes one of the main TTDs in NS and it is rich in natural and cultural attractions. Located in the highland area, it has local commodities such as fruit and vegetable gardens that flourish through the region. There are twenty tourism attractions in the regency and the study examined five of them, which were chosen from nine original samples based on the pilot research completed by researchers and students at University of Sumatera Utara. The selected five TTDs are Bukit Gundaling, Pasar Buah (Fruit Market), Sipiso-piso Waterfall, Desa Lingga, and Bukit Kubu, which have high numbers of visits from the tourists (Fig. 1). 


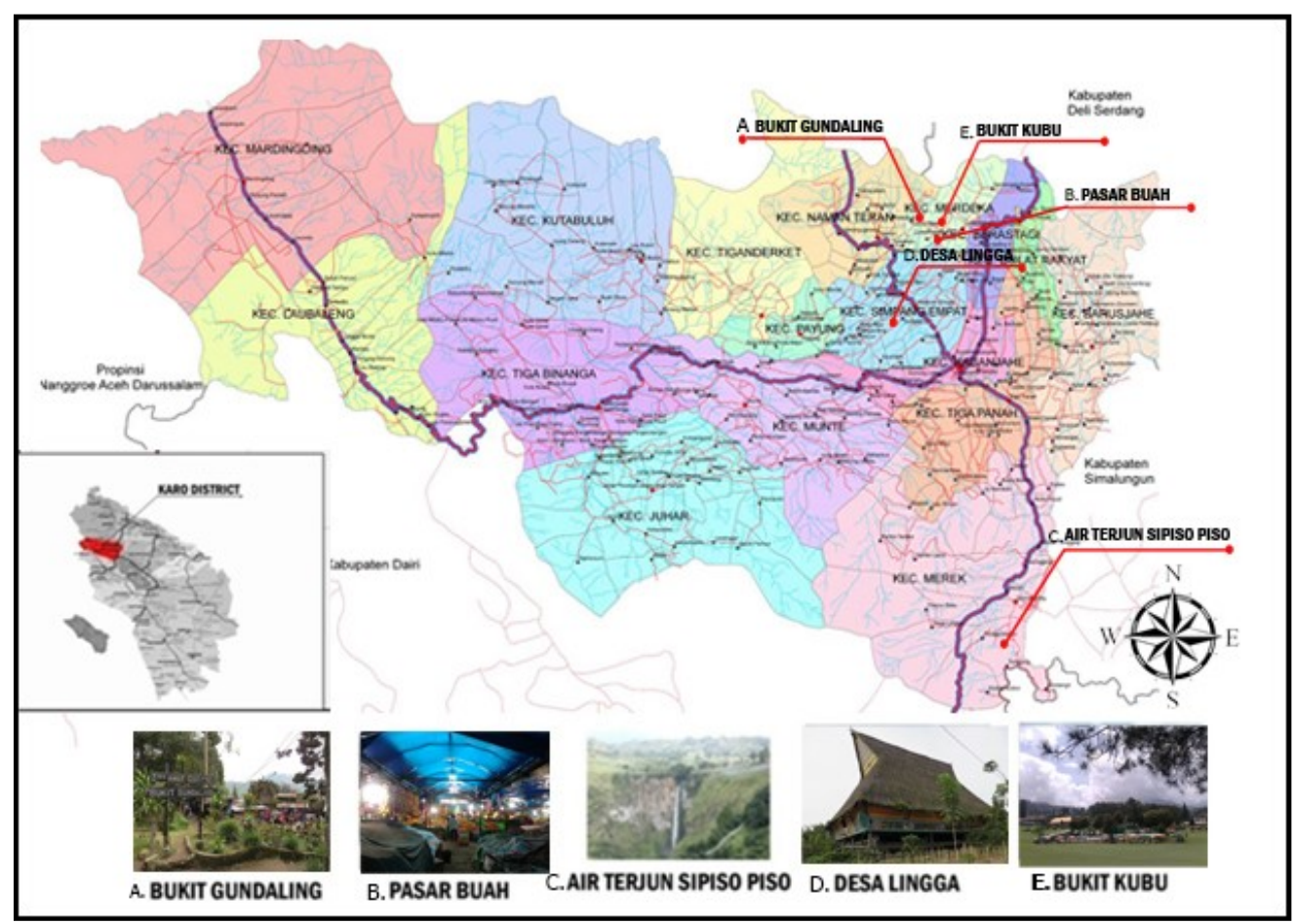

Fig. 1 - Research Areas

Source: Ginting (April and May 2016)

Bukit Gundaling is the highest plateau after Sibayak and Sinabung mounts. The Pasar Buah is located in the Berastagi down town and it becomes a place for various fruits sale. The Sipisopiso Waterfall, one of the largest waterfalls in NS, posits at an altitude of about 800 meters above the sea level and it is surrounded by green pine forests. The Desa Lingga is a historic village where a traditional house aged for more than 250 years remains available, and the last DDT is Bukit Kubu which is placed on a wide hill.

\section{Methods}

The research was conducted in natural TTDs having different people's behaviors towards the TTDs and different levels of knowledge, attitude and culture as well. It combined qualitative and quantitative methods when the respondents' perceptions on the aspects of self-esteem were collected. The first method involving eight in-depth interviews were addressed to tourism stakeholders, such as travel agents, academics, community leaders, government, and respondents who were directly or indirectly engaged in tourism. Meanwhile, field observations were focused on physical data, for instance, physical characteristics, community activities, traditional buildings, facilities, and pedestrian intensity. The second research method involved the questionnaire distribution to 360 respondents, both local people and tourists, and each questionnaire included information on the respondents' profiles (age, gender, status, education, job, occupation, and nationality), their tourism activity (goal, intentions, frequency of visits, and duration), the local tourism events or activities, and on their perceptions on self-esteem aspects (evaluation, pride, attachment, and commitment). 


\section{Results and Discussion}

The study involved 360 respondents in five tourism sites, each represented by 72 respondents comprising of 36 local residents, 22 domestic tourists, and 14 foreign tourists. The foreign tourists dominantly came from Malaysia (54\%) and the rest from Europe (9\%). The respondents had ages ranging from 25-49 years old (46\%) and from 18-24 years old (36\%), while $53 \%$ of them were males. They mostly travelled with friends $(44 \%)$ or in groups $(32 \%)$.

Self-esteem in this study has four variables, namely evaluation, pride, attachment, and commitment. Overall, the self-esteem in TTDs obtained positive assessments from both tourists and local residents (3.22, Table 2).

Table 2

Respondents' perception and the self-esteem principle in research area

\begin{tabular}{|c|c|c|c|c|c|c|c|c|c|c|c|}
\hline \multirow{3}{*}{ Statements } & \multicolumn{2}{|c|}{ Pasar Buah } & \multicolumn{2}{|c|}{ Gunda-ling } & \multicolumn{2}{|c|}{$\begin{array}{l}\text { Sipiso-Piso } \\
\end{array}$} & \multicolumn{2}{|c|}{ Desa Lingga } & \multicolumn{2}{|c|}{ Bukit Kubu } & \multirow[b]{2}{*}{ Total } \\
\hline & $\begin{array}{l}\text { Local } \\
\text { People }\end{array}$ & Tourists & $\begin{array}{l}\text { Local } \\
\text { People }\end{array}$ & Tourists & $\begin{array}{l}\text { Local } \\
\text { People }\end{array}$ & Tourists & $\begin{array}{l}\text { Local } \\
\text { People }\end{array}$ & Tourists & $\begin{array}{l}\text { Local } \\
\text { People }\end{array}$ & Tourists & \\
\hline & Mean & Mean & Mean & Mean & Mean & Mean & Mean & Mean & Mean & Mean & Mean \\
\hline $\begin{array}{l}\text { Easy to find } \\
\text { public toilet }\end{array}$ & 2.64 & 2.94 & 2.88 & 2.39 & 3.00 & 2.72 & 2.33 & 2.39 & 3.11 & 3.28 & 2.77 \\
\hline $\begin{array}{l}\text { Easy to find } \\
\text { information } \\
\text { center }\end{array}$ & 2.86 & 2.72 & 2.97 & 2.67 & 2.69 & 2.72 & 2.36 & 3.00 & 3.25 & 3.25 & 2.85 \\
\hline $\begin{array}{l}\text { Easy to find an } \\
\text { inn }\end{array}$ & 3.11 & 3.33 & 3.16 & 3.25 & 2.78 & 3.08 & 2.36 & 2.69 & 3.47 & 3.58 & 3.08 \\
\hline $\begin{array}{l}\text { Easy to find } \\
\text { restaurant }\end{array}$ & 3.11 & 3.33 & 2.94 & 2.92 & 2.75 & 2.97 & 2.69 & 2.92 & 3.25 & 3.56 & 3.04 \\
\hline $\begin{array}{l}\text { The cost of } \\
\text { lodging at this } \\
\text { place is af- } \\
\text { fordable }\end{array}$ & 3.00 & 3.31 & 2.86 & 3.11 & 2.78 & 3.08 & 2.66 & 3.08 & 3.31 & 3.28 & 3.05 \\
\hline \begin{tabular}{|l|} 
The cost of \\
things in this \\
place is \\
affordable \\
\end{tabular} & 2.83 & 3.28 & 3.02 & 3.11 & 3.19 & 3.14 & 2.86 & 3.22 & 3.25 & 3.19 & 3.11 \\
\hline $\begin{array}{l}\text { The cost of } \\
\text { food/ } \\
\text { beverages in } \\
\text { this place is } \\
\text { affordable }\end{array}$ & 2.78 & 3.33 & 2.97 & 3.19 & 3.14 & 3.08 & 2.97 & 3.17 & 3.33 & 3.33 & 3.13 \\
\hline $\begin{array}{l}\text { I am proud with } \\
\text { the history of } \\
\text { this place }\end{array}$ & 3.06 & 3.33 & 3.25 & 3.31 & 3.19 & 3.44 & 3.47 & 3.72 & 3.33 & 3.53 & 3.36 \\
\hline \begin{tabular}{l|} 
I am proud \\
with the \\
physical \\
symbols/ \\
characteristics \\
of this place \\
\end{tabular} & 3.06 & 3.61 & 2.91 & 3.42 & 3.28 & 3.33 & 3.44 & 3.58 & 3.22 & 3.53 & 3.34 \\
\hline $\begin{array}{l}\text { I feel that I am } \\
\text { a part of this } \\
\text { place }\end{array}$ & 3.25 & 2.94 & 3.16 & 2.83 & 3.44 & 3.11 & 3.61 & 2.53 & 3.39 & 3.36 & 3.16 \\
\hline $\begin{array}{l}\text { This place is } \\
\text { important to } \\
\text { me }\end{array}$ & 3.14 & 3.14 & 3.22 & 2.72 & 3.25 & 3.03 & 3.55 & 2.86 & 3.56 & 3.44 & 3.19 \\
\hline $\begin{array}{l}\text { This place } \\
\text { speaks alot } \\
\text { about me } \\
\end{array}$ & 3.03 & 2.81 & 3.02 & 2.39 & 3.22 & 2.86 & 3.47 & 2.36 & 3.33 & 3.06 & 2.95 \\
\hline $\begin{array}{l}\text { feel happy } \\
\text { when I am in } \\
\text { this place } \\
\end{array}$ & 3.22 & 3.36 & 3.33 & 3.25 & 3.31 & 3.39 & 3.55 & 3.39 & 3.56 & 3.89 & 3.42 \\
\hline $\begin{array}{l}\text { I feel the same } \\
\text { with this place }\end{array}$ & 3.28 & 3.08 & 3.19 & 2.89 & 3.28 & 3.06 & 3.5 & 2.81 & 3.69 & 3.50 & 3.23 \\
\hline \begin{tabular}{|l|} 
I'm sad if the \\
characteristics \\
of this place \\
are gone \\
\end{tabular} & 3.47 & 3.75 & 3.58 & 3.58 & 3.47 & 3.53 & 3.86 & 4.06 & 3.86 & 4.03 & 3.72 \\
\hline $\begin{array}{l}\text { feel sad if the } \\
\text { characteristics } \\
\text { of this place } \\
\text { are gone }\end{array}$ & 3.39 & 3.75 & 3.63 & 3.58 & 3.50 & 3.58 & 3.88 & 4.06 & 4.03 & 4.19 & 3.76 \\
\hline \begin{tabular}{|l|} 
If I could, I \\
want to spend \\
more time in \\
this place
\end{tabular} & 3.19 & 3.56 & 3.33 & 3.31 & 3.31 & 3.28 & 3.38 & 3.39 & 3.64 & 3.75 & 3.41 \\
\hline \begin{tabular}{|l|} 
I want to con- \\
tribute to the \\
development \\
of this place \\
\end{tabular} & 3.00 & 3.17 & 3.38 & 3.11 & 3.47 & 3.36 & 3.61 & 3.25 & 3.53 & 3.94 & 3.38 \\
\hline & & & $\begin{array}{l}=\text { Evalu } \\
\text { Value }\end{array}$ & $\begin{array}{l}=\text { Pride } \\
1=\text { stron }\end{array}$ & $\begin{array}{l}\text { ttachm } \\
\text { sagree }\end{array}$ & $\begin{array}{l}C=\text { Cor } \\
\text { trongly }\end{array}$ & & & & & 3.22 \\
\hline
\end{tabular}


The self-esteem in the fruit market was well-appreciated by the residents and tourists who gave a high value on the tourist attraction and they felt proud of it. Indeed, they would feel sad if the market disappeared or it was destroyed. Similarly, the residents and tourists also had positive responses to Bukit Gundaling. In the Sipiso-piso Waterfall, the local residents and tourists were happy and proud of the attraction. Last, in Desa Lingga, the tourists and the local residents felt proud of the history and characteristics of the village. In fact, a stronger sense of belonging, pride, and ties will grow by the involvement of the local communities in the preservation of historic areas (Ginting 2014). For instance, the travelers and residents stated that they would feel sad if Desa Lingga was lost or it was destroyed. This became high assessments of selfesteem for the tourist site. Furthermore, a person would be happy with a place with physical symbols that made them feel proud of and it would avoid a place that caused no pride (Twigger -Ross et al. 2003). With regard to the findings, Bukit Kubu was awarded to have a good rating from the residents and tourists because they felt the TTD liked a home because they could perform daily activities, i.e., playing, picnic, eating in the restaurant and outbounds.

A positive or negative evaluation of a place indicates whether or not the place is worth visiting, so it can make the area better (Twigger-Ross and Uzzel 1996). The identity of a place affects the visitor's attitude to the impact of tourism resulting in a positive and negative evaluation (Wang and $\mathrm{Xu}$ 2015). In a tourism destination, this evaluation involves many factors (Suwantoro 2004) and it relates to the visitor's satisfaction to the place (Sulistiyana et al. 2015, Sivalioğlu and Berköz 2016). Thus, it is vital to the development of tourism in an area.

As one of the factors in evaluating a place, public toilets contribute to creating a comfortable environment (Ja'afar et al. 2012). In the studied area, the easiness of finding public toilets obtained poor rating by the average respondents. The public toilets in the fruits market were not available at strategic locations (Fig. 2), making them difficult for travelers to find them and there were no signs guiding the tourists to the public toilets. Furthermore, the ease to find the information center was also poorly rated in the studied tourist sites. Moreover, the quality of services and facilities, as well as the satisfaction to the two aspects would improve the longterm relationship with the tourists and it made them comfortable to the place. Therefore, the further improvement of facilities was required.
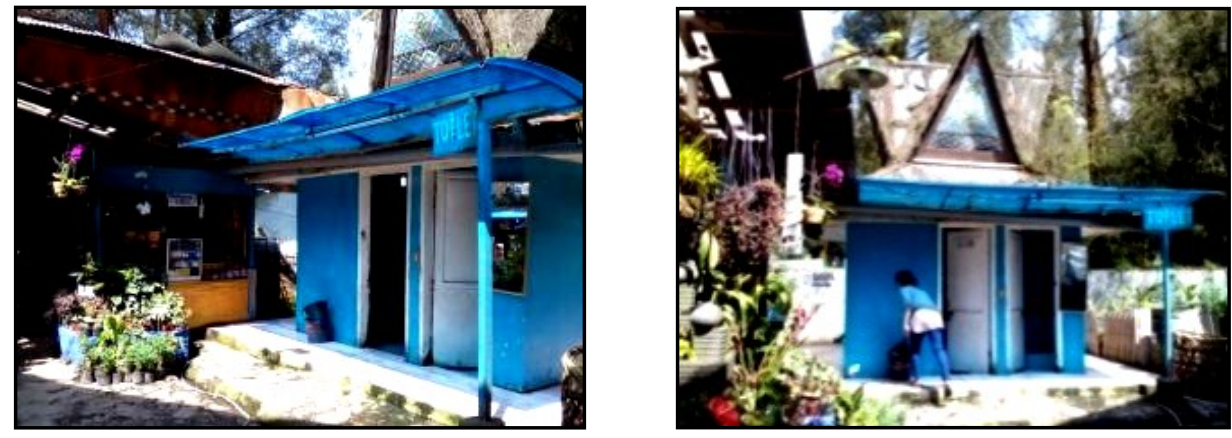

Fig. 2 - Public toilet in Pasar Buah Source: Ginting (May 2016)

In contrast, the study found that accommodations for foreign and domestic tourists were at easy access especially in Bukit Kubu. The restaurants in Bukit Kubu also got a high assessment rating from the respondents although small places selling food required further management (Fig. 3). Lastly, the costs of lodging in TTDs were quite affordable. In Bukit Kubu, there were accommodations available for tourists with affordable costs and the following is an 
example of interview with a respondent: "The cost of lodging in Bukit Kubu is quite affordable, and it has good tourism attractions. Tourists can also enjoy the panorama of the Green Hill from the inn there" (Main respondent: Tourism Figures).
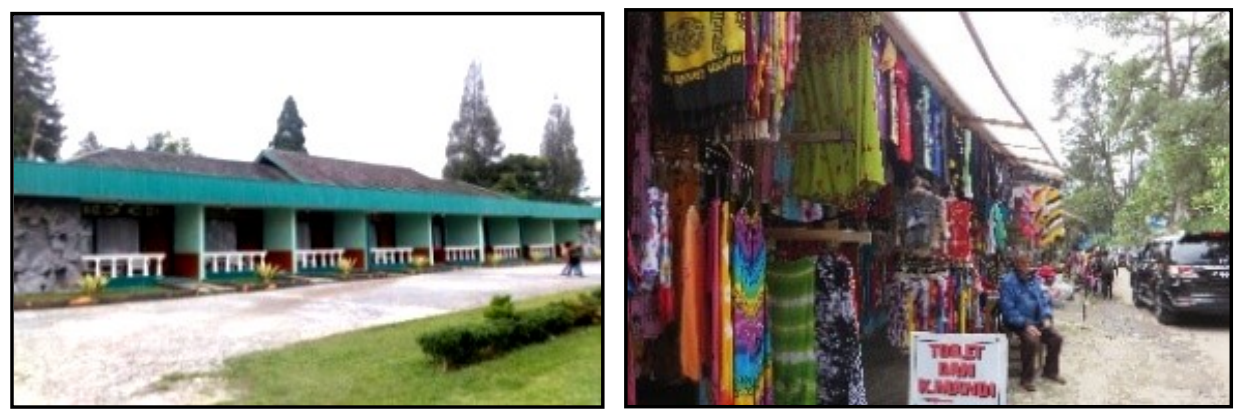

Fig. 3 - Lodgings in Bukit Kubu and stores in Bukit Gundaling Source: Ginting (May 2016)

Prices could also influence the respondents' perception that determined the kind of experience they expected during their visits to a TTD (Middleton et al. 2009). The research shows that prices of goods in tourism sites were affordable for tourists; meanwhile, local people gave a low assessment for goods in tourism sites. The following is an interview with a key respondent: "The admission price to the tourism attractions in Karo Regency is affordable for domestic and foreign tourists, and so are the prices of goods, food, and beverages" (Main respondent: Tourism Figures)

In general, the price of goods, as well as food and beverages, gave a positive evaluation towards the area. Moreover, food and beverages in the tourism attractions were also easy to find as indicated by the number of restaurants and stalls available around the tourism spots.

People will be happy with a place with visible symbols that gives them a sense of pride and they will avoid the area that gives them the opposite situation (Twigger-Ross et al. 2003). Furthermore, the existence of historic buildings also gave them a feeling of proudness to the society due to the memories of the past which enhance the sense of pride and of belonging to the place. In Karo's TTDs, respondents felt generally proud of the history of the place, and among the five objects of research, Desa Lingga received the highest rating regarding to its status as a traditional village in Karo with its traditional houses that have been existed for around 250 years. The following is an interview with a key respondent: "The historical attraction in Karo Regency is Desa Lingga which have been granted facilities by the Government and will be soon renovated. The whole indigenous culture is in Desa Lingga with historical potentials, such as the traditional houses" (Main respondent: Karo District Government Leader).

Historic buildings will give a sense of pride for tourists and residents (Ginting et al. 2018) and Desa Lingga even becomes the main attraction for tourists to visit (Fig. 4). In addition, the physical symbols or characters in Karo tourism sites were considerably high for the respondents. The low level of public and tourists' participations were due to the absence of confidence in the function of the tourism attraction (Rao and Kumar 2017).

Respondents gave positive ratings of pride only to Desa Lingga. The cultural village still maintained relics of unique Karo traditional houses that made tourists and residents feel proud of the place. It proves that cultural symbols would increase the bonding to a place (Shabek 2015). 


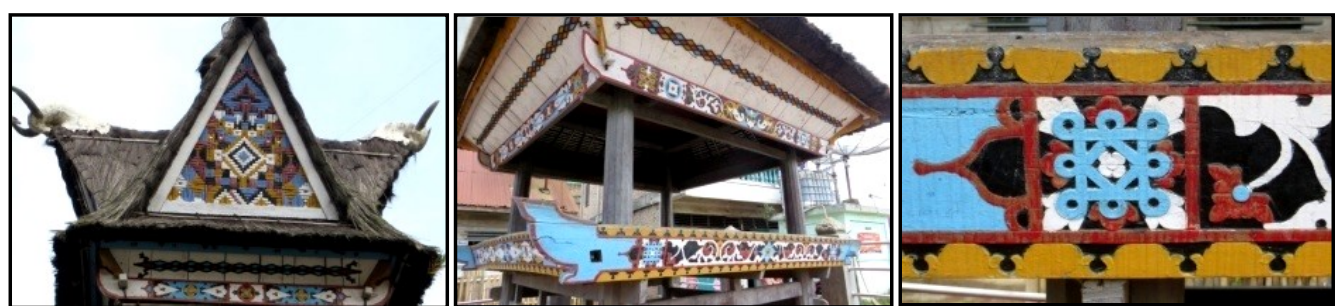

Fig. 4 - Physical symbols and characteristics of traditional houses in Lingga village Source: Ginting (April 2016)

The main characteristics of place attachment becomes someone's desire in order to manage an intimacy with an object (Brown and Perkins 1992). It also describes a particular feeling to a place (Hidalgo and Hernández 2001). In the studied areas such as Berastagi and Sipiso-piso waterfall, people in the TTDs felt that they were part of the place. They enjoyed and felt happy when they were in the locations. However, it can be seen that some tourists still considered themselves as strangers to those places, like Pasar Buah, Bukit Gundaling, and Desa Lingga.

The results show that the five tourism attractions brought less meanings to the foreign tourists, but not to the domestic tourists. Another factor of attachment, that is functional and emotional attachment, also holds significant roles in establishing place identity (Ujang and Dola 2009, Ginting et al. 2017).

In general, respondents were happy in the TTDs. The attachment shows visitors some privacy and family togetherness (Harris et al. 1996). This particularly becomes obvious in Bukit Kubu, where domestic and foreign tourists and local people were very happy to perform various activities together with their families (Fig. 5). This is supported by the following interview with a key respondent: "The most popular tourism attraction by domestic tourists in Karo Regency is at Bukit Kubu. It is often used for meeting place which enables tourists to refresh all day and spend the weekend in Bukit Kubu. It seems that the current tourism attraction trend in Karo Regency is Bukit Kubu" (Main resource: Hotel Manager at Berastagi).
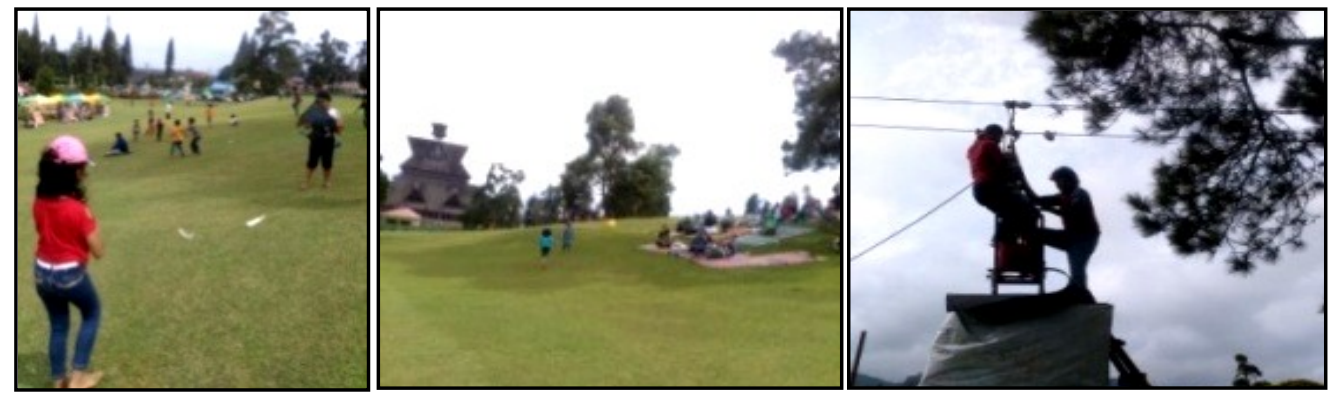

Fig. 5 - Tourist Activities in Bukit Kubu Source: Ginting (May 2016)

Furthermore, respondents also feel merged with the tourism attraction in five TTDs and, as a consequence, they felt sad if the TTDs characteristics were lost. Desa Lingga got the highest rating among the respondents who felt very sad if the village disappeared or it was destroyed. This is supported by an interview with the main respondent: "If Desa Lingga is demolished, we will have difficulties to observe Karo culture. In fact, our weakness in Karo regency is the absence of data or information about the Karo culture, and there are only two real forms of the culture, namely in Dokan and Lingga village. Of course, I will feel such grief if Lingga village's 
characteristics are lost or destroyed" (Main resource: Academician).

Local residents and tourists also felt sad when the tourism attractions in Karo diminished or were destroyed because for them it would be difficult to find attractions and Desa Lingga got the highest rating from the respondents.

Individuals with high self-esteem tend to be more committed than the ones with low selfesteem (Bankone and Ajagun 2014). In order to establish or create a commitment to a place, self-esteem, thus, must be improved. As more tourists visit a site, it will likely become a favorite neighborhood and enhance its self-esteem (Twigger-Ross and Uzzell 1996). Indeed, the rising tourism quality, as well as the commitment of visitors to a particular destination, will motivate them to visit the place more frequently and consequently make the local people more comfortable to live there. This will, in the end, grow a desire to develop the tourism (Fig. 6). In general, tourists and residents in the study area wanted to spend a significant time in the tourism area, and the five locations mostly get a high rating from the tourists and the residents.
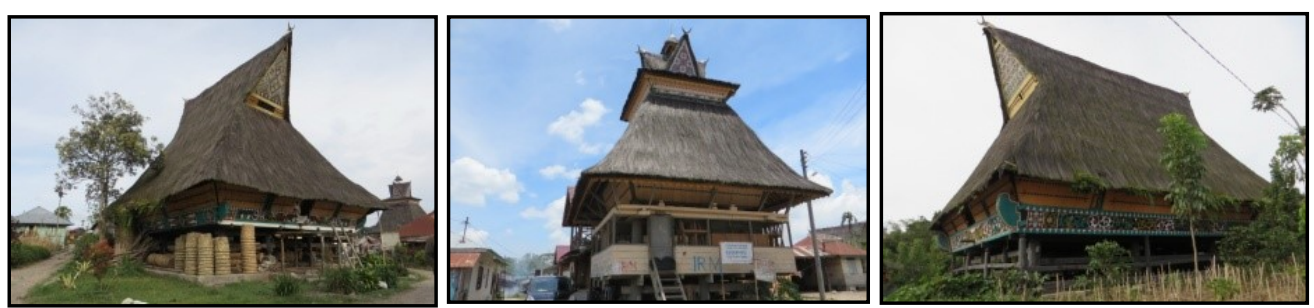

Fig. 6- Desa Lingga traditional houses

Source: Ginting (May 2016)

The research also indicated that the respondents were willing to contribute to the development of TTDs and the five locations mostly got a high rating from the tourists and the residents. They especially gave the highest rating for their commitments in Bukit Kubu, even though it is still well managed until now. However, they wanted the area to be well-developed in the future. It happens similarly to Desa Lingga although it does still need new management for the traditional houses from the government and the local residents as indicated by the following interview: "How do we improve the land of Karo? Throughout the study, seminars and so on, just on this year glance? At the land of Karo and tourism attraction in Desa Lingga, this will be a blow to us that we have to go back there to manage it?" (Main respondent: Academician / Cultural Leader). The increase of self-confidence that grows in the tourism sector has a positive impact on the quality of their lives (Yusof et al. 2012).

\section{Conclusions}

The pride attachment commitment is positive, but the evaluation aspect needs to be raised in quality. In the aspect of evaluation reviewed regarding the ease of finding public toilets is still lacking in Karo District, the capacity also is still insufficient and not strategic, so it needs additional public facilities in tourist locations. Nonetheless, in case of evaluation, tourism in Karo is considered poor since the tourists feel it difficult to find public facilities such as toilets or information centers; therefore, there is a need for an evaluation of the physical quality of the environment which should be improved to support the tourism development.

In the aspect of pride, local and foreign tourists feel very sad to see their TTDs uninteresting or destroyed but they are proud of the history and physical symbols available in the TTDs; therefore, they are committed to the development of tourism. In the aspect of attachment, in general, people in the TTDs felt that they were part of the place and they enjoyed and felt 
happy when they were in the locations, but some tourists still considered themselves as strangers to the places. Attachment was found to Lingga village and not in the 4 TTDs, so it needs buildings with a unique character and local people with a high meaning; attachments for tourists are not too important as they are more important to the community and the local tourists are not too important to the outside tourists. In the aspect of commitment in general, tourists and residents wanted to spend a significant time in the tourism area while the five locations mostly get a high rating from the tourists and the residents.

As Basnezhin (2015) argued, the quality of facilities in the tourism attraction supports the creation of pride and of long-term relationships with the tourists which makes them willing to come back. The preservation of traditional buildings in Desa Lingga Village will avoid it from losing its character. We recommend further research on self-esteem in the other TTDs in Karo regency.

Moreover, the physical symbols of a typical character should be improved, because they can distinguish the place from other places, increasing the unique character. High pride is found in the special characters of social buildings. The evaluation is low but it can be improved while some are interesting. It turns out that because the place is unique, they are proud while the tourists are also proud and satisfied. Besides that, they have a commitment, even though they are physically improved; the local attachments are high and they feel a lack of attachment but they are committed. We recommend further research on attachment and evaluation on the commitment in the other TTDs in Karo regency.

\section{Acknowledgements}

The research was funded by the Directorate of Research and Community Service, Directorate General of Research and Development Affirmation, Indonesian Ministry of Research, Technology and Higher Education, based on the Letter of Agreement on the Implementation Assignment of Research Program with Grant No. 017/SP2H/LT/DRPM/II/2016, dated February 17, 2016. We also thank students at the Department of Architecture, Faculty of Engineering, University of Sumatera Utara.

\section{References}

BAJRACHARYA S. (2015), Measures of violence: Rumor publics and politics in the Kathmandu Valley, Journal of Material Culture 20 (4), 361-378.

BANKONE E. T., AJAGUN O. V. (2014), Psychological Contract and Organizational Based Self Esteem as Antecedents of Organizational Commitment among Government Workers in Ekiti State, Nigeria, International Journal of Research in Humanities and Social Studies 1 (2), 24-33.

BAZNESHIN S. D., HOSSEINI S. B., AZERI A. R. K. (2015), The Physical Variables of Tourist Areas to Increase the Tourists' Satisfaction Regarding the Sustainable Tourism Criteria: Case Study of Rudsar Villages, Sefidab in Rahim Abad, Procedia - Social and Behavioral Sciences 201, 128-135.

BERNARDO F., PALMA J. M. (2005), Place Change and Identity Processes, Medio Ambiente y Comportamiento Humano 6 (1), 71-87.

BONAIUTO M., BREAKWELL G. M., CANO I. (1996), Identity Processes and Environmental Threat: The Effects of Nationalism and Local Identity upon Perception of Beach Pollution, Journal of Community \& Applied Social Psychology 6 (3), 157-175.

BROWN B. B., PERKINS D. D. (1992), Disruptions in Place Attachment, in: Altman I., Low S. M. (eds.), Place Attachment, Plenum Press, New York, pp. 279-304.

GINTING N. (2014), Disertasi identiti tempat dan pengaruhnya terhadap pelancongan warisan, kajian Kes Bandar Medan Indonesia, Universiti Sains Malaysia, Penang. 
GINTING N., WAHID J. (2015), Exploring Identity's Aspect of Continuity of Urban Heritage Tourism, Procedia - Social and Behavioral Sciences 202, 234-241.

GINTING N., RAHMAN N. V. (2016a), Maimoon Palace Heritage District in Medan, Indonesia: What We Preserve and Why We Preserve?, Procedia - Social and Behavioral Sciences 222, 332-341.

GINTING N., RAHMAN N. V. (2016b), Preserve Urban Heritage District based on Place Identity, Asian Journal of Environment-Behaviour Studies 1 (1), 67-77.

GINTING N., RAHMAN N. V., NASUTION A. D. (2017), Increasing Tourism in Karo District, Indonesia Based on Place Identity, Environment - Behaviour Proceedings Journal 2 (5), 177-184

GINTING N., RAHMAN N. V., SUBHILHAR S., WAHID J. (2018), The Role of Place Identity in Planning Heritage Tourism, The Indonesian Journal of Planning and Development 3 (2), 56-66.

GUSTAFSON P. (2001), Roots and Routes: Exploring the Relationship between Place Attachment and Mobility, Environment and Behavior 33 (5), 667-686.

HAUGE A. L. (2007), Identity and place: a critical comparison of three identity theories, Architectural Science Review 50 (1), 44-51.

HARRIS P. B., BROWN B. B., WERNER C. M. (1996), Privacy regulation and place attachment: Predicting attachments to a student family housing facility, Journal of Environmental Psychology 16 (4), 287-301.

HIDALGO M. C., HERNÁNDEZ B. (2001), Place attachment: Conceptual and empirical questions, Journal of Environmental Psychology 21 (3), 273-281.

JA'AFAR N. H., SULAIMAN A. B., SHAMSUDDIN S. (2012), The contribution of landscape features on traditional streets in Malaysia, Procedia - Social and Behavioral Sciences 50, 643-656.

LALLI M. (1992), Urban-related identity: Theory, measurement, and empirical findings, Journal of Environmental Psychology 12 (4), 285-303.

MIDDLETON V. T. C., FYALL A., MORGAN M., RANCHHOD A. (2009), Marketing in travel and tourism, Routledge, Oxford.

NORTH SUMATERA CULTURE AND TOURISM OFFICE (2011), Incredible North Sumatera 2011, North Sumatera Culture and Tourism Office, Medan.

PROSHANSKY H. M., FABIAN A. K., KAMINOFF R. (1983), Place-identity: Physical world socialization of the self, Journal of Environmental Psychology 3 (1), 57-83.

RAO C. S., KUMAR D. S. (2017), Decentralisation and Participatory Planning By PriS in Telangana: A Study of Grama Jyothi Programme, Journal of Rural Development 36 (4), 569594.

SHABAK M., NOROUZI N., ABDULLAH A. M., KHAN T. H. (2015), Children's Sense of Attachment to the Residential Common Open Space, Procedia - Social and Behavioral Sciences 201, 39-48.

SIVALIOĞLU P., BERKÖZ L. (2016), Relationship between place attachment and user satisfaction at some national parks in Turkey, ITU J Faculty Arch. 13 (1), 171-181.

SULISTIYANA R. T., HAMID D., AZIZAH D. F. (2015), Pengaruh Fasilitas Wisata Dan Harga Terhadap kepuasan Konsumen (Studi Pada Museum Satwa), Jurnal Administrasi Bisnis 25 (2), 1-9.

SUWANTORO G. (2004), The Basics of Tourism Dasar-dasar Pariwisata, Penerbit Andi, Yogyakarta.

TWIGGER-ROSS C. L., UZZELL D. L. (1996), Place and identity processes, Journal of Environmental Psychology 16 (3), 205-220.

TWIGGER-ROSS C. L., BONAIUTO M., BREAKWELL G. M. (2003), Identity Theories and Enviromental Psychology, in: Bonnes M., Lee T. R. (eds.), Psychological Theories for Environmental Issues, Ashgate, Aldershot, pp. 203-234.

UJANG N., DOLA K. (2009), Linking Activity and Place Attachment Dimensions in Enhanching the Sense of Place, Alam Cipta Fakultirekabentuk dan Senibina, Universiti Putra Malaysia, 59-67. 
UJANG N., ZAKARIYA K. (2015), Place Attachment and the Value of Place in the Life of the Users, Procedia - Social and Behavioral Sciences 168, 373-380.

WANG S., XU H. (2015), Influence of place-based senses of distinctiveness, continuity, self-esteem and self-efficacy on residents' attitudes toward tourism, Tourism Management 47, 241-250.

WANG S. (2016), Roles of place identity distinctiveness and continuity on resident attitude toward tourism, European Journal of Tourism Research 13, 58.

YUSOF Y., IBRAHIM Y., MUDA M. S., AMIN W. A. A. W. M. (2012), Community Based Tourism and Quality of Life, Review of Integrative Business \& Economic Research 1 (1), 336346.

Initial submission: 04.12.2018

Revised submission: 03.04.2019

Final acceptance: 05.07.2019

Correspondence: Department of Architecture, Faculty of Engineering, University of Sumatera Utara, Jalan Dr. T. Mansur, 20155, Medan, Indonesia.

Email: nurlisa@usu.ac.id 
